Title: Theoretical and Experimental Thermal Performance Assessment of an Innovative External Wall Insulation System for Social Housing Retrofit

First author:

Second author:

Third author:

Fourth author:

Fifth author:
Dr Lucelia Rodrigues (corresponding author)

Associate Professor

Department of Architecture and Built Environment

Faculty of Engineering, University of Nottingham

Lucelia.Rodrigues@nottingham.ac.uk

University Park, NG7 2RD, Nottingham, UK

Office: 0044 (0) 1159513167

ORCID ID: 0000-0002-0038-6578

Dr Jennifer White

Development Officer (Scotland)

The Woodland Trust Scotland

jenniferwhite@woodlandtrust.org.uk

South Inch Business Centre

Perth, Perthshire, PH2 8BW, Scotland UK

Prof Mark Gillott

Chair in Sustainable Building design

Department of Architecture and Built Environment

Faculty of Engineering, University of Nottingham

Mark.Gillott@nottingham.ac.uk

University Park, NG7 2RD, Nottingham, UK

Office: 0044 (0) 1158467677

ORCID ID: 0000-0002-4829-8243

Emily Braham

Head of Sustainable Energy

Nottingham City Homes

emily.braham@nottinghamcityhomes.org.uk

Beechdale Court, Beechdale Road, NG8 3LH, Nottingham, UK

Mobile: 0044 (0) 7824134811

Office: 0044 (0) 1158762048

Assim Ishaque

Managing Director

Envirup Ltd

assim.ishaque@envirup.com

The Nottingham CleanTech Centre

63-67 St Peters Street, Nottingham NG7 3EN

Mobile: 0055 (0) 7976878882

Office: 0044 (0) 8009524244 


\title{
Theoretical and Experimental Thermal Performance Assessment of an Innovative External Wall Insulation System for Social Housing Retrofit
}

\author{
Rodrigues, L., White, J., Gillott, M., Braham, E., Ishaque, A.
}

\begin{abstract}
The UK building stock, being amongst the oldest in the developed world, is also one of the least energy efficient and accounts for approximately $45 \%$ of UK carbon emission. Energy use from housing alone was responsible for $13 \%$ of total UK carbon dioxide and greenhouse gas emissions in 2015 . Therefore, achieving the national target of an $80 \%$ reduction in carbon emissions by 2050 against 1990 baseline conditions is highly dependent on the reduction of energy consumption in dwellings. The complexity of the problem of retrofitting energy saving measures in the extensive and diverse aging housing stock is further compounded due to the number of 'hard to treat' properties that comprise over $40 \%$ of homes in the UK. In this article, the authors present an evaluation of the theoretical and experimental performances of a novel prototype external wall insulation system, developed to improve energy efficiency in 'hard to treat' housing. The system was designed to be primarily used to retrofit social housing, which comprises up to $18 \%$ of the current UK housing stock.
\end{abstract}

A thorough testing regime was undertaken to test the suitability and effectiveness of the new product in the most common social housing construction typologies. This included: an investigation of the theoretical thermal performance of the prototype product through steady state modelling, a laboratory based prototype test, an analysis of empirical data collected from a cross section of social housing properties in Nottinghamshire, UK used to inform whole house dynamic modelling, and the development of dynamic simulations to assess the energy and carbon reduction impacts of the new product. The theoretical modelling suggested that the integration of the system resulted in thermal performance improvements for all construction types with space heating demand reduced by up to $42 \%$. The results of the whole house dynamic modelling assessment also suggested that the addition of the system resulted in a reduction of heating energy demand of up to $49 \%$. The prototyping testing shown that the system is easy to install requirement minimum building skills.

The findings suggest that the new product not only meets the performance of existing external wall insulation systems, but also provides unique selling points with respect to easy installation and non-reliance on weather conditions. The project finished with a pilot study when one house was retrofitted using the novel product.

Keywords: social housing, retrofit, energy efficiency, external wall insulation

\section{Introduction}

The 2010 Energy Performance of Buildings Directive established that all new buildings in Europe must be nearly zero energy buildings by 2020 in an attempt to reduce energy consumption and $\mathrm{CO}_{2}$ emissions. However, in most European countries the annual growth rate of new buildings is currently estimated at around 1-1.5\% of the housing stock (Di Giuseppe et al 2017). In Europe, it is estimated that $80 \%$ of the current building stock will still be in use by 2030 and at least $30 \%$ of those will be continuously occupied for decades (ibid). Therefore, there is great potential for energy savings, and consequently $\mathrm{CO}_{2}$ emissions reduction, in the improvement of existing buildings.

The UK building stock, being amongst the oldest in the developed world, is also one of the least energy efficient and accounts for approximately 45\% of UK carbon emissions (Stafford et al., 2011 p.8). Energy use from housing alone was responsible for $13 \%$ of total UK carbon dioxide and greenhouse gas emissions in 2015, a 4\% increase from 2014 but a significant decrease from the previous decades when it was responsible for up to $27 \%$ (Department for Business, Energy and Industrial Strategy, 2017 p. 26). Therefore, achieving the national target of an $80 \%$ reduction in carbon emissions by 2050 (against 1990 baseline conditions) is highly 
dependent on the reduction of energy consumption in dwellings. The UK has over 8.5 million houses that are in excess of 60 years old (Energy Saving Trust, 2007), resulting in slow progress towards lower domestic carbon emissions through replacement with more efficient properties alone. Around $70 \%$ of these houses are still expected to be in use by 2050 (Stafford et al., 2011 p.8). This poses a dilemma for policy makers, developers and local authorities at the strategic level and home owners at a more localised level - 'is the best solution to abandon older houses (relocation of occupants and major demolition/rebuild projects) or to refurbish and retrofit existing properties?' (Harter et al, 2017a, Harter et al, 2017b, Gaspar et al, 2015, Power, 2008).

The complexity of the problem of retro-fitting energy saving measures in the extensive and diverse aging housing stock is further compounded due to the number of 'hard to treat' properties that comprise over $40 \%$ of homes in the UK (Energy Saving Trust (EST), 2008). This includes solid walled, flat roofed, timber framed and high rise buildings, as well as tenements, park homes and those with limited services connections or no loft space (Roaf, Baker, and Peacock, 2008). In such properties, it can be difficult to improve building fabric performance through standard measures such as cavity wall or loft insulation due to the building structure. There is increasing concern that without more pro-active communication, enhanced incentives, and easier to implement solutions, many of the properties in this category will still not be thermally efficient in 2050 (Dowson et al., 2012).

The determinants of energy use in dwellings are complex and include occupants, equipment, climate and specially the building design and envelope (Santamouris, 2016; Byrne et al, 2016; Gillott et al, 2010). The space heating requirements of a dwelling are dependent upon the balance between whole house heat losses and heat gains and have a heavy influence on its overall energy performance (Feist, Pfluger, Kaufmann, Schnieders, and Kah, 2007). In an uninsulated building, up to $35 \%$ of total heat losses can occur through the external walls (Woodford, 2014). The choice of materials used to construct the building envelope will therefore have a major impact on thermal performance. In order to prevent excessive heat loss in a temperate cold climate such as the UK, a building should be well insulated. This is less problematic in buildings that utilise a cavity wall structure, as using a good quality cavity wall insulation can reduce overall heat losses by up to $60 \%$ (Energy Saving Trust, 2010). However, in solid wall structures or those with narrow cavity spaces, such improvements are not possible (Tetlow et al, 2015). In addition, the choice of construction and retrofit methods will have a direct influence on the resultant indoor air quality (Kolokotsa and Santamouris, 2015).

External or internal wall insulation may be viable options in these cases, but most solutions are expensive, time consuming to install, require highly skilled labour and the installation is generally weather dependent. Internal wall insulation may be cheaper to install than external wall insulation, but it will also reduce the floor area of the rooms in a property as it is installed directly onto the internal surface of the external walls, and may present a higher risk of interstitial condensation and other moisture problems (Bjarløv, et al, 2015). The work associated with the installation may cause inconvenience to occupants, as it requires the removal of skirting boards and architraves and redecoration will be required following installation (Energy Saving Trust (EST), 2010). Consequently, for most cases, external wall insulation is the best solution.

In order to increase the volume housing retrofit, the UK government has been launching since 2013 several supporting measures to fund energy efficiency improvements (Gooding et al, 2017). However, this has not resulted on the expected increase in volume, although is has promoted improvements. Gooding et al (2017) found that to increase retrofit activity in the UK, it was important to focus on improved training for onsite trades, increase business skills to deliver, boost financial support for end users and establish a number of demonstration projects.

Dwellings in the social sector make up 17.2\% of all English housing according to the 2015-16 English Housing Survey (Department for Communities and Local Government, 2017: page 6). This is equivalent to 3.9 million households in England and approximately 5 million homes in the UK, or 18\% (Beckett 2014 p.4). Around 72\% of local authority housing stock and $47 \%$ of the housing association homes were built between 1945 and 
1980. Only $8 \%$ of local authority stock and $37 \%$ of housing association homes were built after 1980 (Department for Communities and Local Government, 2017: page 25).

Because of the government retrofit supporting measures, $48 \%$ of dwellings in the social rented sector presented an energy efficiency rating of A-C in this last survey, compared with $26 \%$ in the private rented sector and $24 \%$ of owner occupied homes (ibid: page 3 ). Although this is of course good news, among social renters, over a quarter $(28 \%)$ are retired and one in five $(21 \%)$ are 'inactive', a group that includes those who have a long-term illness or disability and those who were looking after the family. Social renters are also mostly in the lower income quintiles (45\% were in the lowest income quintile and $27 \%$ in the second lowest). This means that the majority of the occupiers of social housing are amongst the most vulnerable members of the society, who are hit harder by low comfort levels and are less likely to be able to afford the energy costs to keep their homes warm. Many of those households fall below the fuel poverty line (Department for Business, Energy \& Industrial Strategy, 2017). Therefore, there is an urgent need for solutions that enable the rapid retrofit of the social housing sector.

In this article, the authors present an evaluation of the theoretical and experimental performance of an innovative modular prefabricated External Wall Insulation (EWI) system, developed to scale up retrofit activity in the UK, targeting primarily the social housing sector. In addition to providing good insulation capabilities, the product's unique selling points are the easiness of installation (less reliance on skilled labour) and non-reliance on weather conditions. The system was designed by EnvirUP Ltd and was developed by a multidisciplinary team as part of a research project funded by the UK Technology Strategy Board.

\section{An Innovative External Wall Insulation System}

Currently, most existing external wall insulation products consist of an insulation panel board fixed onto the external wall and then covered with a wet external render. The EnvirUP EWI system comprises of a composite panel, produced in highly accurate extrusion made up of $75 \%$ recycled un-plasticised Polyvinyl Chloride (UPVC), filled with a highly insulated material, usually rigid polyurethane (PUR) foam. The panels are attached together by tessellation and the system includes the wall fittings. This can be delivered to site as a complete system and can be installed in any weather conditions, as it removes the requirement for a wet render finish to fix and cover the insulation sheets. It can be finished in a range of textures and colours to reflect the context, building type and customers' preferences. Although details of the system's construction cannot be shared, more information can be found on the company's website (www.envirup.com). The first installation of the system, which took place in Nottingham, UK, can be seen in Figure 1.

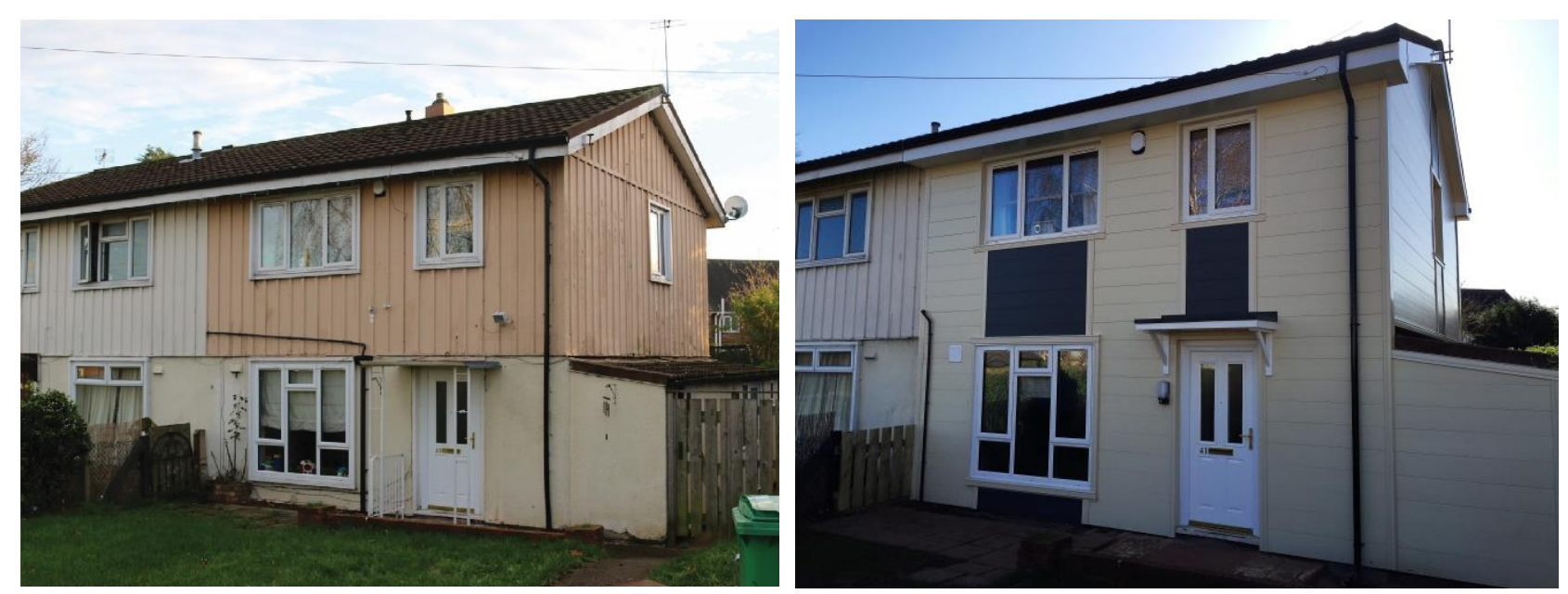

Figure 1: The house that received the first installation of the product before (left) and after (right)

The EnvirUP system is unique when compared to currently available systems, as it has potential for reduced cost, flexibility in the final appearance, and the ability to be fitted in all weathers. It also requires a lower level of installation skills than current systems, and may be fitted in most homes with solid walls and other 
difficult to retrofit construction types. Despite wide search, the team has not found any other comparable modular systems available in the European market.

A funded project allowed the team to develop the product from its initial ideas and intellectual property to its full maturity. In addition to thermal performance assessment work presented here, several other work packages dealt with mechanical characteristics, condensation risk, installation process, labour training, fire resistance, accreditation and costs. Initial thermal modelling was also undertaken to inform the type and thickness of insulating materials to be used, and in order to compare the product with other similar products in the market. These are not discussed in this article but some of it has been published elsewhere (White et al, 2015a and White et al, 2015b). The results of the initial thermal modelling suggested that ideally the final product should achieve a total u-value within the range of $0.22-0.25 \mathrm{~W} / \mathrm{m}^{2} \mathrm{~K}$. However, due to mechanical strength and installation considerations, the final achieved $\mathrm{u}$-value was $0.264 \mathrm{~W} / \mathrm{m}^{2} \mathrm{~K}$ as tested by the UK National Physical Laboratory (National Physical Laboratory (NPL), 2017) using standard assessment procedures to characterise thermophysical properties of materials. Testing undertaken through the project carried out using Bentley Hevacomp V8i modelling software suggested that condensation was not a significant risk for the proposed system as the dew point remained outside the main wall structure. Hevacomp evaluates the risk of condensation occurring both on the surface and interstitially within a building element using the principles detailed in the British Standards (BS) BS 5250 and BS EN ISO 13788.

The final deliverable was the first installation of the product, which allowed the team to verify the effectiveness of the envisaged installation process and capture issues faced on site. Long term monitoring was outside the scope of the project.

\section{Methodology}

Initial work undertaken by the project team informed the decision making process in terms of product composition and overall characteristics, and compared it to existing products in the market. This was followed by the several tests that are presented in this article, undertaken once the product makeup was decided but still opened for small refinement.

Firstly, steady state thermal modelling work was undertaken utilising the Standard Assessment Procedure (SAP) protocols, using the SAPPER 12 software (RUSFA, 2017). SAP is the methodology used by the UK Government to assess and compare the energy and environmental performance of dwellings (Department for Business, Energy and Industrial Strategy, 2014).

Three models of representative dwellings were built and tested to replicate characteristics typically found in social housing based on data from the Building Research Establishment and the English Housing Survey (Building Research Establishment (BRE), 2002; Building Research Establishment (BRE), 2012; Department for Communities and Local Government, 2017). In England, around 30\% of social housing are terrace houses, $18 \%$ are semi-detached and less than $0.5 \%$ are detached (Department for Communities and Local Government, 2017: page 27). Flats make up around 40\% of the accommodation but these were not considered for the system developed due to mechanical limitations.

The typology and construction materials of the properties studied were selected by project partners Nottingham City Homes, Nottingham's main social housing provider, based on a) number of properties of these types in Nottingham (to ensure replicability and potential economies of scale) and b) properties that are 'hard to treat' and therefore more troublesome and expensive to retrofit. The three models used in this work were built based on characteristics of actual properties found in Nottingham. These were:

1. End terrace solid brick wall property,

2. Mid-terrace cross-wall property, typically made up of insitu reinforced concrete load-bearing party walls and timber-framed front and rear elevation, and 
3. Semi-detached British Iron and Steel Federation (BISF) wall property, which were pre-fabricated steel frame.

The plans of the houses can be seen in Figure 2 and the characteristic of each are represented in Table 1. Please note that the houses were not compared against each other and therefore it was more important to represent homes that are typical of the social housing stock than to fix the characteristics across the models. The results are presented in Section 4: Steady State Performance Assessment.

Table 1: Construction Details used in SAP Analysis

\begin{tabular}{|c|c|c|c|c|c|c|c|}
\hline & $\begin{array}{c}\text { Area } \\
\left(\mathrm{m}^{2}\right)\end{array}$ & $\begin{array}{c}\text { Volume } \\
\left(\mathrm{m}^{3}\right)\end{array}$ & $\begin{array}{c}\text { Wall } \\
\text { u-value } \\
\left(\mathrm{W} / \mathrm{m}^{2} \mathrm{~K}\right)\end{array}$ & $\begin{array}{c}\text { Floor } \\
\text { u-value } \\
\left(\mathrm{W} / \mathrm{m}^{2} \mathrm{~K}\right)\end{array}$ & $\begin{array}{c}\text { Roof } \\
\text { u-value } \\
\left(\mathrm{W} / \mathrm{m}^{2} \mathrm{~K}\right)\end{array}$ & $\begin{array}{c}\text { Window } \\
\text { u-value } \\
\left(\mathrm{W} / \mathrm{m}^{2} \mathrm{~K}\right)\end{array}$ & $\begin{array}{c}\text { Door } \\
\text { u-value } \\
\left(\mathrm{W} / \mathrm{m}^{2} \mathrm{~K}\right)\end{array}$ \\
\hline $\begin{array}{l}\text { 1. End terrace solid } \\
\text { brick dwelling }\end{array}$ & 76.30 & 173.96 & 2.82 & 0.50 & 0.55 & 2.50 & 3.00 \\
\hline $\begin{array}{l}\text { 2. Mid-terrace } \\
\text { cross-wall dwelling }\end{array}$ & 76.30 & 173.96 & 0.44 & 0.50 & 0.55 & 2.50 & 3.00 \\
\hline $\begin{array}{l}\text { 3. Semi-detached } \\
\text { BISF dwelling }\end{array}$ & 82.94 & 199.89 & 0.84 & 0.50 & 0.55 & 2.50 & 3.00 \\
\hline
\end{tabular}

\begin{tabular}{|l|l}
\hline Property type \\
brick dwelling \\
(all external walls \\
and party wall are \\
solid brick; \\
suspended timber \\
floors)
\end{tabular}

Figure 2: The typical social houses selected for the study (note that north is towards the top of the page in all plans)

Secondly, prototypes of the wall types used in the steady state modelling were built and tested in a climate chamber facility at the University of Nottingham. The chamber enabled the use of different weather data patterns to simulate a range of external and internal environmental conditions. The Envirup EWI system was then installed on the wall prototypes and further testing was undertaken to assess the product's performance 
in comparison to the baseline. Both, steady state and dynamic u-value tests were undertaken. The results are presented in Section 5: Experimental Performance Assessment.

Thirdly, empirical data collected from a cross section of social housing properties in Nottinghamshire, UK was analysed and used to inform whole house dynamic modelling. The results are presented in Section 6: Empirical Data Analysis.

Finally, dynamic simulations of the three models of typical dwellings utilising EDSL TAS 9.3.6.1 were undertaken in order to provide an overall assessment of the energy and carbon reduction impacts of the system. The results are presented in Section 7: Dynamic Performance Assessment informed by the Empirical Data.

\section{Steady State Performance Assessment}

An assessment of the thermal performance of the EnvirUP system was developed using SAPPER 12 (RUSFA, 2017) software. The software is based upon the principles of the SAP 2012. Models of the three typical houses represented in Figure 2 and Table 1 were built as base cases. Next, the models were 'retrofitted' with the Envirup EWI system whilst all other assumptions were kept the same in order to simulate the improvement in performance that could be attributed to the system alone. Table 2 summarises the results obtained from the SAP simulations in terms of SAP rating, total carbon emissions, primary energy demand and space heating demand. Table 3 summarises the percentage of reduction achieved on each measure.

It can be seen that, for all construction types, the inclusion of the Envirup EWI system within the model resulted in an improvement in thermal performance. This was expected as it reflects the improvement in uvalue of the walls. Of particular significance, were the improvements for the solid wall and the BISF properties. Carbon emissions in these were reduced by $34 \%$ and $28 \%$ respectively due to the addition of the Envirup EWI system. Similarly, the space heating demand in these properties were reduced by $42 \%$ and $36 \%$ respectively.

Table 2: Results from SAP 2012 Simulations

\begin{tabular}{|l|c|c|c|c|}
\hline & SAP rating & $\begin{array}{c}\text { Carbon Emissions } \\
\left(\mathrm{kWh} / \mathrm{m}^{2} / \mathrm{yr}\right)\end{array}$ & $\begin{array}{c}\text { Primary Energy } \\
\text { Demand } \\
\left(\mathrm{kWh} / \mathrm{m}^{2} / \mathrm{yr}\right)\end{array}$ & $\begin{array}{c}\text { Space Heating } \\
\text { Demand } \\
\left(\mathrm{kWh} / \mathrm{m}^{2} / \mathrm{yr}\right)\end{array}$ \\
\hline $\begin{array}{l}\text { 1. End terrace solid brick } \\
\text { dwelling - uninsulated }\end{array}$ & 61 & 4.96 & 257.85 & 127.92 \\
\hline $\begin{array}{l}\text { 1. End terrace solid brick } \\
\text { dwelling - with Envirup EWI }\end{array}$ & 72 & 3.28 & 171.53 & 73.72 \\
\hline $\begin{array}{l}\text { 2. Mid-terrace cross-wall } \\
\text { dwelling - uninsulated }\end{array}$ & 71 & 3.45 & 180.29 & 79.08 \\
\hline $\begin{array}{l}\text { 2. Mid-terrace cross-wall } \\
\text { dwelling - with Envirup EWI }\end{array}$ & 72 & 3.18 & 166.07 & 70.40 \\
\hline $\begin{array}{l}\text { 3. Semi-detached BISF } \\
\text { dwelling - uninsulated }\end{array}$ & 59 & 5.20 & 270.35 & 140.70 \\
\hline $\begin{array}{l}\text { 3. Semi-detached BISF } \\
\text { dwelling - with Envirup EWI }\end{array}$ & 68 & 3.76 & 196.30 & 90.47 \\
\hline
\end{tabular}


Table 3: Results from SAP 2012 Simulations in \% of reduction between uninsulated and Envirup EWI

\begin{tabular}{|l|c|c|c|}
\hline & $\begin{array}{c}\text { Carbon Emissions } \\
\text { Reduction (\%) }\end{array}$ & $\begin{array}{c}\text { Primary Energy Demand } \\
\text { Reduction (\%) }\end{array}$ & $\begin{array}{c}\text { Space Heating Demand } \\
\text { Reduction (\%) }\end{array}$ \\
\hline $\begin{array}{l}\text { 1. End terrace solid brick } \\
\text { dwelling }\end{array}$ & 34 & 33 & 42 \\
\hline $\begin{array}{l}\text { 2. Mid-terrace cross-wall } \\
\text { dwelling }\end{array}$ & 8 & 8 & 11 \\
\hline $\begin{array}{l}\text { 3. Semi-detached BISF } \\
\text { dwelling }\end{array}$ & 28 & 27 & 36 \\
\hline
\end{tabular}

This was not as pronounced in the case of the cross-wall house, as the u-value of the wall prior to the addition of the EWI within the wall construction build-up was much lower than for the solid brick wall and BISF properties. The improvement in performance for the cross-wall house is still notable though, with a reduction in space heating requirements in the region of $11 \%$, and a carbon saving of $8 \%$. However, the cost of EWI installation may make the payback period unfeasibly long for this type of property. It is a more attractive investment proposition when considering the solid brick wall and BISF house constructions, as the annual savings in heating bills could be in excess of one third of the total costs prior to the addition of the installation. These types of properties would also have a more significant impact on reducing domestic carbon emissions, in line with EU and UK targets.

\section{Experimental Performance Assessment}

This experimental work aimed to address several key areas, namely: practical installation process, effectiveness of the backing foam, thermal performance of the EnvirUP panel and potential condensation risk. In this article, only the results of the thermal performance testing are described.

A climate testing thermal chamber facility at the University of Nottingham has been used in order to do this, where different weather data patterns were used to simulate a range of external and internal environmental conditions. Three different wall types were tested representing the walls found in the selected solid brick wall property, the cross-wall property and the BISF wall property. The cross-wall and the BISF wall were represented by a concrete wall and a plywood board wall, which are representation of the largest surfaces found in these construction types.

The authors used a calibrated hot-box approach and followed the procedure suggest by the British Standards Institution (1999). This consists of an indoor/hot side chamber and an outdoor/cold side chamber. All walls within the hot box have high thermal properties to minimise heat loss through any pathway other than the sample being studied. The sample being tested is placed between the two chambers, and the energy flow through the material is measured as heat transfer from the hot to the cold sides of the sample. It is known as the 'calibrated hot box' as an initial test is conducted with a sample of known u-value, and losses are calculated to the surrounding environment. The performance of the test sample is then compared to the results of the calibration test in order to determine losses due to the test sample (British Standards Institution, 1999).

The opening between the two chamber rooms was infilled using a partition made of studwork and $300 \mathrm{~mm}$ Celotex insulation panels. Within this partition, a series of $900 \mathrm{~mm} \times 1000 \mathrm{~mm}$ wall samples were constructed. This set-up is shown in Figure 3. Heat flux plates and thermocouples were fixed to both sides of the wall sample structures. The information collected enabled heat flows and temperatures on the internal and external surfaces to be monitored, and this data was used to assess in-situ u-value and responses of the internal and external wall surfaces to temperature differences. 
Several environmental scenarios were applied to the panel within the thermal chamber. The first was a steady state analysis, where internal and external conditions were maintained at a constant of $25^{\circ} \mathrm{C}$ and $5^{\circ} \mathrm{C}$ respectively, in order to obtain an in-situ u-value. Following this, a real weather file for Nottingham was applied to the external conditions, while the interior temperature was maintained at $20^{\circ} \mathrm{C}$. The third scenario involved varying the internal temperature between $18^{\circ} \mathrm{C}$ and $22^{\circ} \mathrm{C}$ in order to mimic heating patterns, whilst applying the same weather data as in the second testing phase. This final test utilised both the real weather data and the internal heating pattern data in order to assess the effect of variation that would be similar to a real world situation. The testing scenarios are summarised in Table 4.

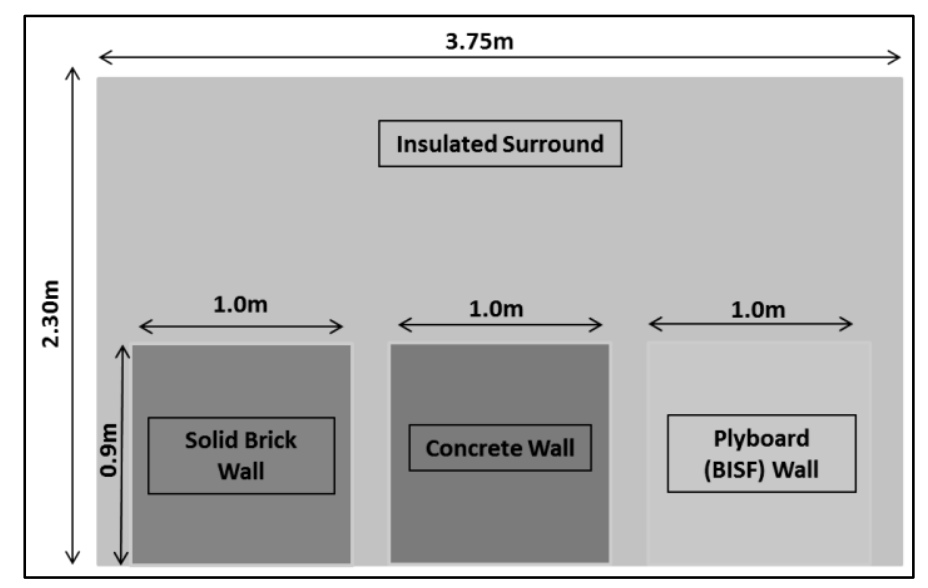

Figure 3: Position of the wall constructions in the thermal chamber

Table 4: Experimental testing Scenarios

\begin{tabular}{|l|c|c|}
\hline Scenarios tested & External Temperature $\left({ }^{\circ} \mathrm{C}\right)$ & Internal Temperature $\left({ }^{\circ} \mathrm{C}\right)$ \\
\hline $\begin{array}{l}\text { 1. Uninsulated u-value } \\
\text { steady state analysis }\end{array}$ & 5 & 25 \\
\hline $\begin{array}{l}\text { 2. Uninsulated dynamic } \\
\text { climate analysis }\end{array}$ & $1-10$ & 20 \\
\hline $\begin{array}{l}\text { 3. Insulated u-value } \\
\text { steady state analysis }\end{array}$ & 5 & 25 \\
\hline $\begin{array}{l}\text { 4. Insulated dynamic } \\
\text { climate analysis }\end{array}$ & $1-10$ & 20 \\
\hline $\begin{array}{l}\text { 5. Insulated space } \\
\text { heating analysis }\end{array}$ & $1-10$ & $18-22$ \\
\hline
\end{tabular}

Table 5: Steady state v-value results from experimental testing

\begin{tabular}{|c|c|c|c|c|c|c|c|c|}
\hline & \multicolumn{4}{|c|}{ Measured in Chamber } & \multicolumn{4}{|c|}{ Theoretical from Modelling } \\
\hline & 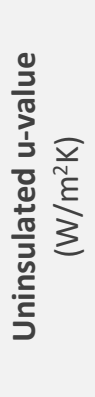 & 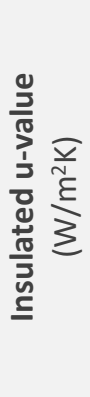 & 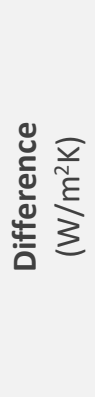 & 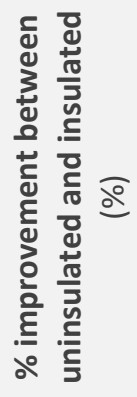 & 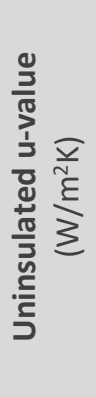 & 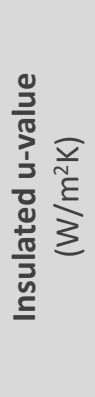 & 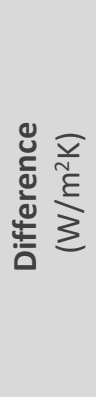 & 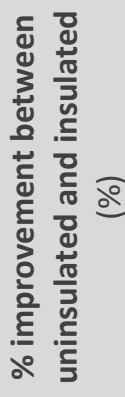 \\
\hline BISF Wall & 2.07 & 0.59 & 1.48 & 71 & 1.7 & 0.27 & 1.43 & 84 \\
\hline Brick Wall & 2.56 & 0.53 & 2.03 & 79 & 2.21 & 0.28 & 1.93 & 87 \\
\hline Concrete Wall & 0.56 & 0.18 & 0.38 & 68 & 0.47 & 0.18 & 0.29 & 61 \\
\hline
\end{tabular}


The results from the steady state experimental $u$-value testing for both the uninsulated and insulated wall sections (scenarios 1 and 3 in Table 4) are shown in Table 5 and Table 6. Several tests were undertaken and the rig was improved and adjusted after each; the results presented are the best case results only.

The difference between the theoretical u-value measurement and the best case in-situ steady state measurement was in the order of $10-15 \%$, depending on the wall type being considered. There has been a significant amount of academic and industry research to investigate the accuracy of in-situ u-value measurements. It has been observed that deviations in construction u-values can range from $30 \%$ to over $160 \%$ as compared to the u-value stated by the manufacturer and therefore used in theoretical models (Siviour, J. B., 1994; Wingfield, J. et al., 2011a; Wingfield, J. et al., 2008; Zero Carbon Hub, 2013a. Baker (2011) undertook in-situ u-value measurements on 57 different wall constructions, utilising heat flux sensors to measure heat flow through the material under consideration and temperature sensors to monitor internal and external temperatures. The study found that $44 \%$ were lower, $42 \%$ were approximately equal to, and $14 \%$ were higher than, the calculated value (Baker, 2011, p. 24). Doran (2000) examined 29 separate building elements in order to assess the standard protocols for calculating u-values (Building Standards Institute, 2008a) and reasons for divergence between calculated and measured performance. It was observed that the calculation methodology underestimated heat losses by up to approximately $30 \%$ (Doran, 2000, p. 25).

As the steady state testing has shown such a significant difference, and in order to assess the influence of external climatic conditions on the thermal performance of the EnvirUP EWI system, dynamic tests were also undertaken in the chamber (scenarios 2, 4 and 5 in Table 4). This comprised of a period of time where the internal temperature of the chamber was maintained at $20^{\circ} \mathrm{C}$, whilst the temperature of the external climate room was varied between $0^{\circ} \mathrm{C}$ and $10^{\circ} \mathrm{C}$. The initial temperatures were the same inside and outside the chamber before the chamber was warmed up. This was completed on all three wall sample types in both an insulated and uninsulated state, with results shown in Figure 4 . The black areas on the graphs depict the moving average of the $u$-value of the wall sample, which is useful in visualising trends within the data.

In the case of the uninsulated wall samples, the brick wall demonstrated the greatest response to the changes in external temperature, with the $\mathrm{u}$-values varying between 1.59 and $3.88 \mathrm{~W} / \mathrm{m}^{2} \mathrm{~K}$, and an average $\mathrm{u}$-value of $2.42 \mathrm{~W} / \mathrm{m}^{2} \mathrm{~K}$. The BISF wall shows some response, but this is less marked than the brick wall sample. The measured u-value varies between 1.08 and $2.79 \mathrm{~W} / \mathrm{m}^{2} \mathrm{~K}$, with the average $\mathrm{u}$-value being $1.95 \mathrm{~W} / \mathrm{m}^{2} \mathrm{~K}$. The concrete wall displayed the most resistance to climatic influences, which is not surprising given that it already had a lower u-value. A maximum u-value of $1.42 \mathrm{~W} / \mathrm{m}^{2} \mathrm{~K}$ and minimum value of $0 \mathrm{~W} / \mathrm{m}^{2} \mathrm{~K}$ was calculated for this wall sample, with a mean of $0.51 \mathrm{~W} / \mathrm{m}^{2} \mathrm{~K}$. The $0 \mathrm{~W} / \mathrm{m}^{2} \mathrm{~K}$ value was found when the temperatures inside and outside the chamber were the same.

When the EnvirUP insulation product was applied to the wall samples, the solid brick wall demonstrated a marked improvement in terms of resistance to changes in external temperature. The measured u-values ranged from 0 to $1.10 \mathrm{~W} / \mathrm{m}^{2} \mathrm{~K}$, with a mean of $0.29 \mathrm{~W} / \mathrm{m}^{2} \mathrm{~K}$. The BISF wall sample showed a slight improvement (u-values of between $0 \mathrm{~W} / \mathrm{m}^{2} \mathrm{~K}$ and $1.32 \mathrm{~W} / \mathrm{m}^{2} \mathrm{~K}$, with mean of $0.47 \mathrm{~W} / \mathrm{m}^{2} \mathrm{~K}$ ), while the concrete wall displayed a very similar response to that shown in the uninsulated cycle test (minimum, maximum and mean u-values of $0 \mathrm{~W} / \mathrm{m}^{2} \mathrm{~K}, 1.28 \mathrm{~W} / \mathrm{m}^{2} \mathrm{~K}$ and $0.19 \mathrm{~W} / \mathrm{m}^{2} \mathrm{~K}$ respectively). The $0 \mathrm{~W} / \mathrm{m}^{2} \mathrm{~K}$ value was found when the temperatures inside and outside the chamber were the same. This is as would be expected, as the wall construction is the most thermally effective.

The results from this experimental testing showed a difference between the predicted and measured uvalues of the product in the case of all wall constructions, both in an insulated and uninsulated states. This is not necessarily unexpected, as previous studies mentioned have demonstrated that this can occur as a result of the installation and experimental processes. However, it is obvious from the work that the EnvirUP system does have a positive effect on the resistance of the external wall to climatic changes. This is particularly pronounced in the case of the solid brick wall construction. 


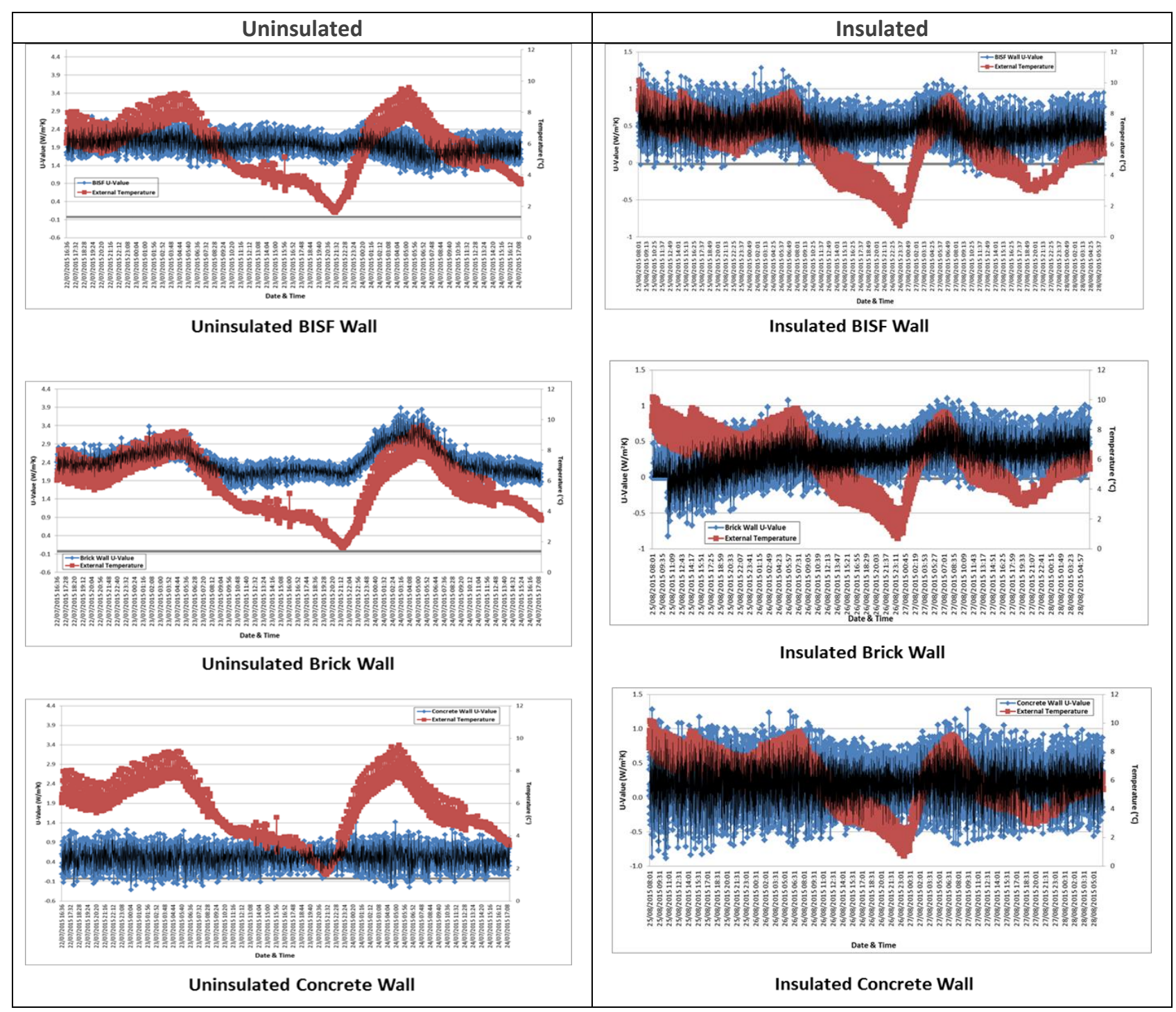

Figure 4: Dynamic u-values results from experimental testing

Whilst the u-values calculated as a result of the experimental work were less favourable than the theoretical results, the EnvirUP system has been found to be thermally effective. In addition, there appears to be little risk of condensation and subsequent problems with damp and mould, and the product was found to be quick and easy to install with minimal training. Therefore, this indicates that the new product has the potential to significantly reduce household space heating bills.

\section{Empirical Data Analysis}

Whilst the building fabric, structure and condition of a property will have an influence on household energy consumption, the occupancy profile can also have a substantial effect (Jones at al, 2016). In low-income housing, comfort has been found to be more important in encouraging take up of energy efficiency measures, (Langevin et al 2013), and in rented properties the energy consumption may be higher than in owneroccupied homes (Leth-Petersen and Togeby 2001). This includes social housing and tenanted dwellings. Santin et al (2009) observed, based on statistical modelling of data from 15,000 households, that approximately $40 \%$ of differences in energy usage can be attributed to building characteristics, whilst occupant profile accounted for around $5 \%$ of variation observed. Gill et al (2010) undertook a study of 13 two-bedroom and nine three-bedroom houses, plus four one bedroom flats, each constructed to the same design specification. The findings showed that occupant behaviour was responsible for variations of $51 \%$, $37 \%$, and $11 \%$ in heat, electrical, and water consumption respectively. Amongst these, heating was found to 
have the higher impact on bills and occupiers' comfort, but also found to not present set standards such as heating setpoint value and heating periods (Jones at al, 2016).

In order to inform the dynamic modelling work presented in the next section, the authors used empirical data collected from a cross section of social housing properties managed by Nottingham City Homes in Nottinghamshire, UK, to evaluate the effect of different occupant profiles on the energy usage in dwellings. An analysis of energy consumption and internal environmental conditions was studied alongside occupant profile. This was published in detail elsewhere (White et al, 2015a) but some data is presented here to support the assumption used in the dynamic modelling.

Nottingham City Homes manages a portfolio of approximately 29,000 social housing dwellings and 1,000 leasehold homes within the city of Nottingham on behalf of Nottingham City Council (Nottingham City Homes, 2008, web). As part of ongoing work to better understand the needs and behaviours of the tenants and occupants, a number of these properties have been fitted with a monitoring system in order to gather data relating to household energy consumption and comfort/ environmental conditions. The wireless monitoring system included meters for electricity and gas and sensors located in the main habitable rooms in order to record ambient air and radiator surface temperature. In some cases, additional sensors were positioned to allow monitoring of the opening of windows and doors.

This study used the information gathered from the monitoring systems, alongside qualitative details of the households (building fabric, installed systems and occupants), in order to better understand the impact of the occupant(s) on the energy consumption of the building. In some instances, complete data was not available for all of the properties due to loss of system data or incomplete responses from occupants. A final sample of 24 dwellings was identified as having sufficient data to be used within this work, and these are presented in Table 6.

Gas consumption data was only available for a limited number of dwellings. As it can be seen in Figure 5, in all cases, gas usage was higher in the winter months than in the summer months. BISF 3 shows the lowest level of seasonal variance, and the property also displays minimal change in internal conditions across the year (Figure 6), although an average internal temperature of around $17^{\circ} \mathrm{C}$ is considerably lower than generally acceptable comfort levels. It is interesting to note that the cavity wall insulated dwelling displayed the greatest variance and also the highest winter gas consumption levels. This is surprising, as it would generally be assumed that this type of property is more thermally efficient than several others within the sample. It is probable that user behaviour is responsible for this apparent anomaly, although this cannot be proved using the information available for this study.

Table 6: Household identification coding

\begin{tabular}{|c|c|c|c|c|c|c|c|c|c|c|c|}
\hline Household ID & BSIF 1 & BSIF 2 & BSIF 3 & $\begin{array}{l}\text { BRICK } \\
\text { SEMI } 1\end{array}$ & $\begin{array}{c}\text { BRICK SEMI } \\
2\end{array}$ & $\begin{array}{l}\text { BRICK } \\
\text { SEMI } 3\end{array}$ & $\begin{array}{l}\text { BRICK } \\
\text { SEMI } 4\end{array}$ & $\begin{array}{c}\text { BRICK } \\
\text { TERRACE } \\
1\end{array}$ & \begin{tabular}{|c|} 
BRICK \\
TERRACE \\
$\mathbf{2}$ \\
\end{tabular} & \begin{tabular}{|c|} 
BRICK \\
TERRACE \\
$\mathbf{3}$ \\
\end{tabular} & $\begin{array}{c}\text { CONCRETE } \\
1\end{array}$ \\
\hline No. Adults & 1 & 1 & 1 & 3 & 2 & 1 & 1 & 3 & 2 & 3 & 2 \\
\hline No. Children & 2 & 3 & 3 & 1 & 0 & 0 & 0 & 0 & 0 & 3 & 2 \\
\hline$\underbrace{n}_{\tilde{D}}$ & 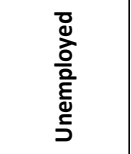 & 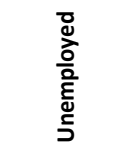 & 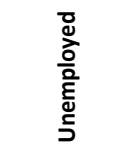 & 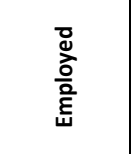 & 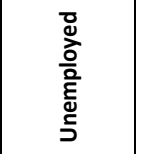 & 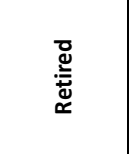 & & & 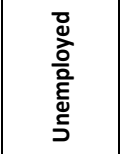 & 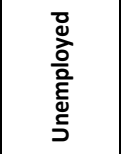 & 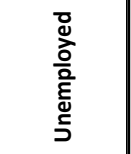 \\
\hline CONCRETE 2 & $\begin{array}{c}\text { CONCRETE } \\
3\end{array}$ & $\begin{array}{c}\text { CONCRETE } \\
4\end{array}$ & $\begin{array}{c}\text { CONCRETE } \\
5\end{array}$ & $\begin{array}{c}\text { CONCRETE } \\
6\end{array}$ & $\begin{array}{c}\text { CONCRETE } \\
7\end{array}$ & $\begin{array}{c}\text { CONCRETE } \\
8\end{array}$ & $\begin{array}{c}\text { CONCRETE } \\
9\end{array}$ & $\begin{array}{l}\text { CAVITY } \\
\text { FILL } 1\end{array}$ & $\begin{array}{l}\text { CAVITY } \\
\text { FILL } 2\end{array}$ & $\begin{array}{l}\text { CAVITY } \\
\text { FILL } 3\end{array}$ & $\begin{array}{l}\text { CAVITY } \\
\text { FILL } 4\end{array}$ \\
\hline 2 & 3 & 5 & 2 & $?$ & $?$ & $?$ & $?$ & 1 & 1 & 2 & 1 \\
\hline 0 & 0 & 0 & 2 & $?$ & $?$ & $?$ & $?$ & 0 & 0 & 4 & 0 \\
\hline 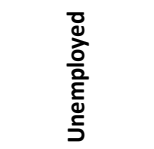 & 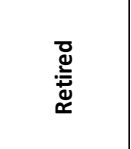 & 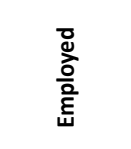 & 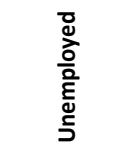 & 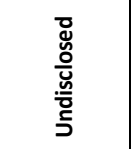 & 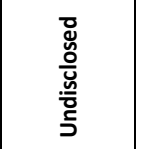 & 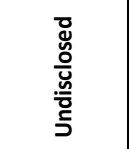 & 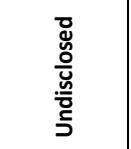 & 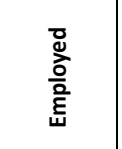 & 总 & 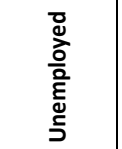 & 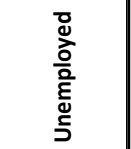 \\
\hline
\end{tabular}




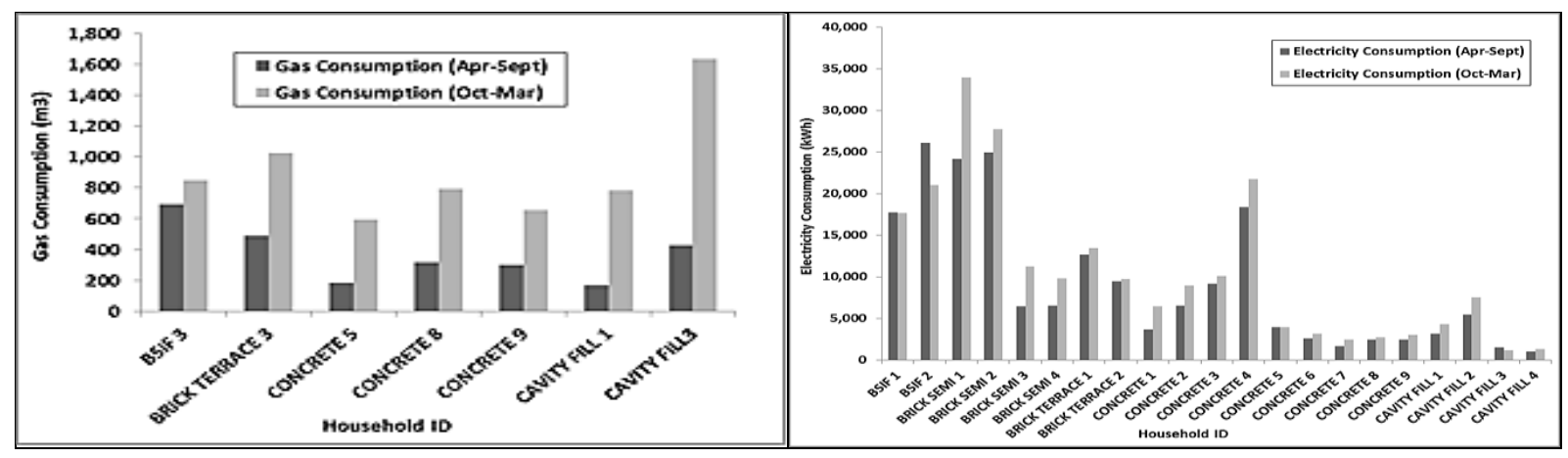

Figure 5: Gas consumption (left) and electricity consumption (right) per household studied

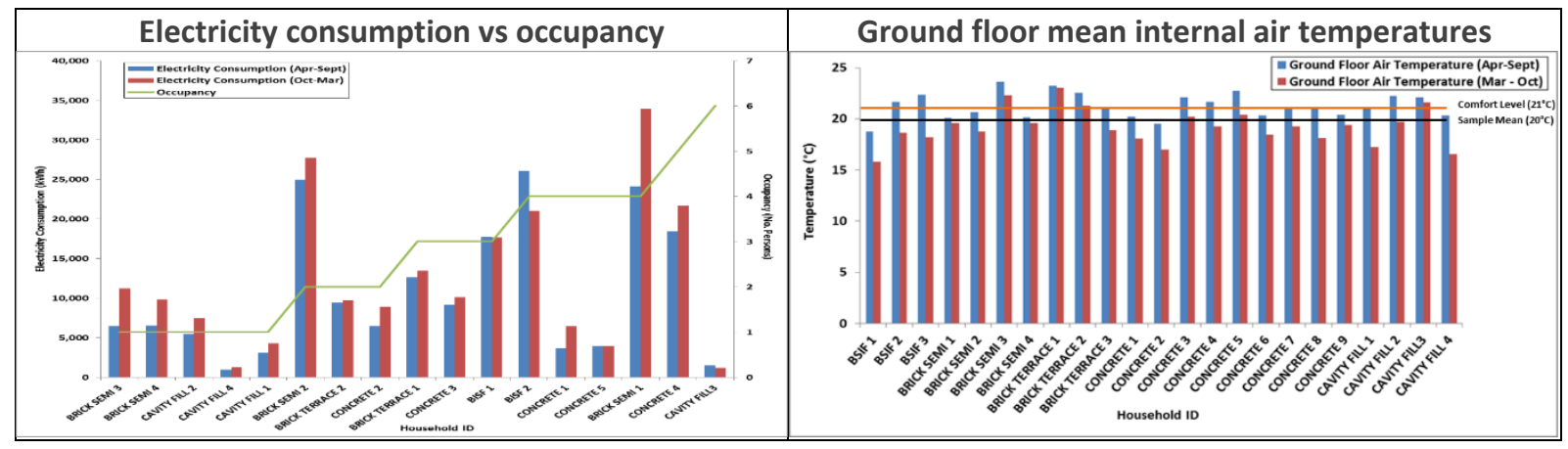

Figure 6: Electricity consumption vs occupancy (left) and ground floor mean seasonal internal air temperature (right)

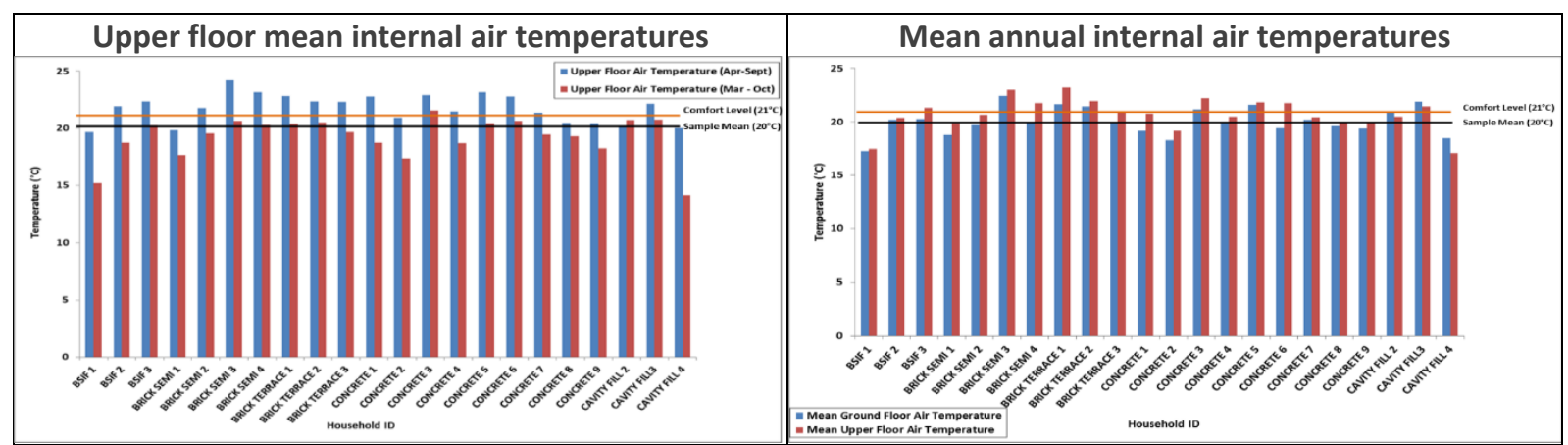

Figure 7: Upper floor mean seasonal internal air temperature (left) and mean annual internal air temperature by household (right)

Concrete 8 and Concrete 9 are located in the vicinity of one another and have the same build type. Unfortunately, the occupancy profile of these dwellings has not been disclosed. However, it can be seen that summer gas consumption is very similar but there is a more marked difference in winter usage. It could be that the typology and behaviour of the occupants is responsible for this variation.

When considering the electricity consumption, there are some trends apparent within the data, as shown in Figure 5 . With the exception of BISF 2, the electricity consumption in the winter months is higher than it is in the summer months. This is as would be expected, due to increased lighting requirements and possible auxiliary space and water heating needs. The more thermally efficient properties, such as the concrete properties and cavity wall insulated dwellings (approximate u-value $0.40 \mathrm{~W} / \mathrm{m} 2 \mathrm{~K}$ ) demonstrated significantly lower levels of monitored metered electricity consumption than the solid brick wall and BISF properties. This could be due to the lack of requirement for supplementary electrical heating, or because of a different energy tariff such as Economy 7. There does not seem to be a significant level of correlation between occupancy levels, numbers of residents and electrical consumption.

Figure 6 (left) displays the electricity consumption per household alongside the number of occupants residing in the property. It can be seen that there is no obvious correlation between number of people in a dwelling and electrical consumption, with a single occupancy cavity fill property using the same amount of electricity 
as a six person household, and both of these properties demonstrating the lowest levels of electrical consumption. It is difficult to isolate the effect of household size on electrical usage, as this is highly dependent on the appliances and electrical goods that are used by the occupants, and general behaviour and approach to energy efficiency (e.g. whether people switch off lights and appliances when not in use).

The temperature profile of the dwellings provided a reliable reflection of the comfort conditions that the occupants live within. Figures 6 and 7 illustrate the mean seasonal temperature profile of the upper and lower floors of the dwellings under consideration. It is interesting to note that, in all cases, the air temperature is consistently lower in the winter than in the summer months. In several instances, it is concerning to note that the ground floor temperatures were very low, with the lowest recorded temperature being approximately $14^{\circ} \mathrm{C}$ (the sensors were placed in the main living rooms). Cavity Fill 3 was amongst the highest internal temperatures within the sample, and had the highest gas consumption levels. However, with two adults and four children living within the dwelling, it is not surprising that comfort levels would be of optimum concern.

There is generally a greater difference observed between winter and summer data seasonal variation within the upper floor air temperatures. The upper floor is usually warmer than the lower floor, and the summer temperatures are almost consistently higher than the winter temperatures. This is not surprising, given the standard heat transfer process that occurs in most buildings.

Figure 7 (right) illustrates the trends occurring within the annual mean temperature data for the upper and lower floors of each of the sample properties. It can be seen that the profiles of each dataset follow the same trend for each dwelling. The properties of the least thermally efficient construction type (BISF) generally display the lowest temperatures, with the exception of Cavity Fill 4, which has extremely low internal temperatures for a property of this type. This is thought to be due to the occupant behaviour (a single resident), rather than due to the building being in poor condition.

The findings revealed that occupants undoubtedly have an impact upon building energy performance. However, due to the interrelated factors of building type, energy consumption, limited sample and household profile/ occupant characteristics, it is difficult to isolate the sole impact of occupancy on energy consumption in a real-life context. However, the evidence suggests that, regardless of occupancy, the thermal performance of the building envelope has a central role in achieving comfortable and stable internal environmental conditions for occupants, alongside lower energy demands. Therefore, retrofit of existing housing, and therefore the research associated with new insulation solutions, is a worthwhile venture. The data was also useful to inform the settings of the models used for dynamic simulations, presented in the next section.

\section{Dynamic Performance Assessment informed by the Empirical Data}

A model of each of the typical selected houses (Figure 2 and Table 1) were developed in EDSL TAS 9.2.1.6 (EDSL, 2010) in order to represent the main construction types of the social housing stock in Nottingham and in the UK. The whole year energy requirements were calculated for the Nottingham climate through a series of dynamic simulations. EDSL TAS performs a dynamic simulation of the thermal processes occurring in a building, including heat transfer, thermal inertia, various modes of ventilation, the effect of active system, etc, in order to provide detailed analysis of its energy performance. This is obtained by considering a series of hourly snapshots of the thermal state of the building, which together provide the energy performance of the building for a predefined period, up to one year (EDSL, 2009). The benefits of using a dynamic simulation tool as oppose to only using the steady state tools include more flexibility in terms of how to account for occupancy and the exploration of the influence of factors such as thermal mass.

The whole building analysis was performed in two parts: simulation of the houses described in Section 3 without insulation on the external walls and simulation of the houses with walls insulated with the EnvirUP prototype system. For the purposes of the analysis each building was divided into the following zones: 
Kitchen/Dining Room, Living Room, Circulations 1 and 2, Bathroom and WC, Bedrooms 1 and 2 and Master Bedroom. The BISF property was simulated with its original glass wool insulation even though some of the walls of these properties would need to be refurbished and its original insulation replaced.

In order to perform the simulations, a number of inputs were entered into the model. These inputs were based on reasonable assumptions regarding the use of the building, the climate, occupancy patterns, heat gains, and heating patterns. For the purposes of this analysis, the following assumptions were considered:

- Weather: The recommended Chartered Institution of Building Services Engineers (CIBSE) Test Reference Year for Nottingham was used (CIBSE, 2006);

- Calendar: The cooling period was set from May to September and the heating period from the October to April;

- Occupancy gains: were assumed to be $95 \mathrm{~W}$ per person, $65 \mathrm{~W}$ sensible and $30 \mathrm{~W}$ latent in the bedrooms and $130 \mathrm{~W}$ per person, $75 \mathrm{~W}$ sensible and $55 \mathrm{~W}$ latent in the living areas; occupant schedule can be found in Table 8 and was fixed across all models and simulations;

- Lighting gains: low-energy light bulbs resulting lighting loads of $30 \mathrm{~W}$ were assumed (Table 8).

- Equipment and appliances: in the living room, these were assumed as the use of a TV for 5 hours/day, a hi-fi system or similar for 3 hours/a day and a laptop for 3 hours/day; summing up to a total load of $1.36 \mathrm{kWh}$ per day. In the kitchen these were assumed as a kettle, a microwave oven, a cooker, a dishwasher, an oven and a fridge, summing up to $4.46 \mathrm{~kW}$.

- Infiltration rate was considered at $0.5 \mathrm{ACH}$ in all zones based on an average value provided by Nottingham City Homes; the Envirup system should not have an influence on air tightness as it does not break through the breathing membrane;

- Heating: assumed on during the winter at specific schedule (Table 8); the temperature set point was considered to be $21^{\circ} \mathrm{C}$ for all zones; this was done in order to enable the comparison of the results, despite the fact that the analysis of the empirical data revealed that indoor temperatures were very different across different properties;

- Ventilation: no natural or mechanical ventilations were assumed for simplicity and clarity of results but the authors have taken this into account when looking at the summer performance.

In 2016 CIBSE updated their test Reference Year file (1984-2013 instead of 1986-2005) to include more recent changes in the UK weather occurred after the year 2000 (CIBSE, 2016). This was not yet available when the work presented here was developed. However, in a study by Eames et al (Eames, Ramallo-Gonzalez et al. 2016) the updated files were found to be very similar to the original set in character in terms of temperature distribution and number of heating/cooling degree hours.

Table 7: Occupancy, lighting and heating schedules (1 indicates occupied/on, 0 indicates unoccupied/off)

\begin{tabular}{|c|c|c|c|c|c|c|c|c|c|c|c|c|c|c|c|c|c|c|c|c|c|c|c|c|}
\hline & -1 & $N$ & $m$ & ナ & in & 6 & 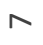 & $\infty$ & $\sigma$ & 윽 & $ت$ & $\stackrel{\sim}{\sim}$ & $\stackrel{m}{\sim}$ & $\stackrel{\vec{A}}{ }$ & $\stackrel{\sim}{\sim}$ & $\stackrel{\varphi}{\sim}$ & ને & $\stackrel{\infty}{\sim}$ & $\stackrel{\rightarrow}{\rightarrow}$ & ㄱ & $\vec{\sim}$ & N & $\stackrel{\mathscr{N}}{\sim}$ & $\stackrel{\sim}{\sim}$ \\
\hline $\begin{array}{l}\text { Bedrooms } \\
\text { occupancy }\end{array}$ & 1 & 1 & 1 & 1 & 1 & 1 & 0 & 0 & 0 & 0 & 0 & 0 & 0 & 0 & 0 & 0 & 0 & 0 & 0 & 0 & 0 & 1 & 1 & 1 \\
\hline $\begin{array}{l}\text { Bedrooms } \\
\text { lighting }\end{array}$ & 0 & 0 & 0 & 0 & 0 & 1 & 0 & 0 & 0 & 0 & 0 & 0 & 0 & 0 & 0 & 0 & 0 & 0 & 0 & 0 & 0 & 1 & 1 & 0 \\
\hline $\begin{array}{l}\text { Living room } \\
\text { Occup/lighting }\end{array}$ & 0 & 0 & 0 & 0 & 0 & 0 & 0 & 0 & 0 & 0 & 0 & 0 & 0 & 0 & 0 & 0 & 1 & 1 & 1 & 1 & 1 & 0 & 0 & 0 \\
\hline Kitchen lighting & 0 & 0 & 0 & 0 & 0 & 0 & 0 & 1 & 0 & 0 & 0 & 0 & 0 & 0 & 0 & 0 & 0 & 1 & 1 & 1 & 0 & 0 & 0 & 0 \\
\hline $\begin{array}{l}\text { Bathroom } \\
\text { lighting }\end{array}$ & 0 & 0 & 0 & 0 & 0 & 0 & 1 & 1 & 0 & 0 & 0 & 0 & 0 & 0 & 0 & 0 & 0 & 1 & 0 & 1 & 0 & 0 & 0 & 0 \\
\hline Heating (winter) & 0 & 0 & 0 & 0 & 0 & 1 & 1 & 1 & 0 & 0 & 0 & 0 & 0 & 0 & 0 & 0 & 1 & 1 & 1 & 1 & 1 & 0 & 0 & 0 \\
\hline
\end{tabular}




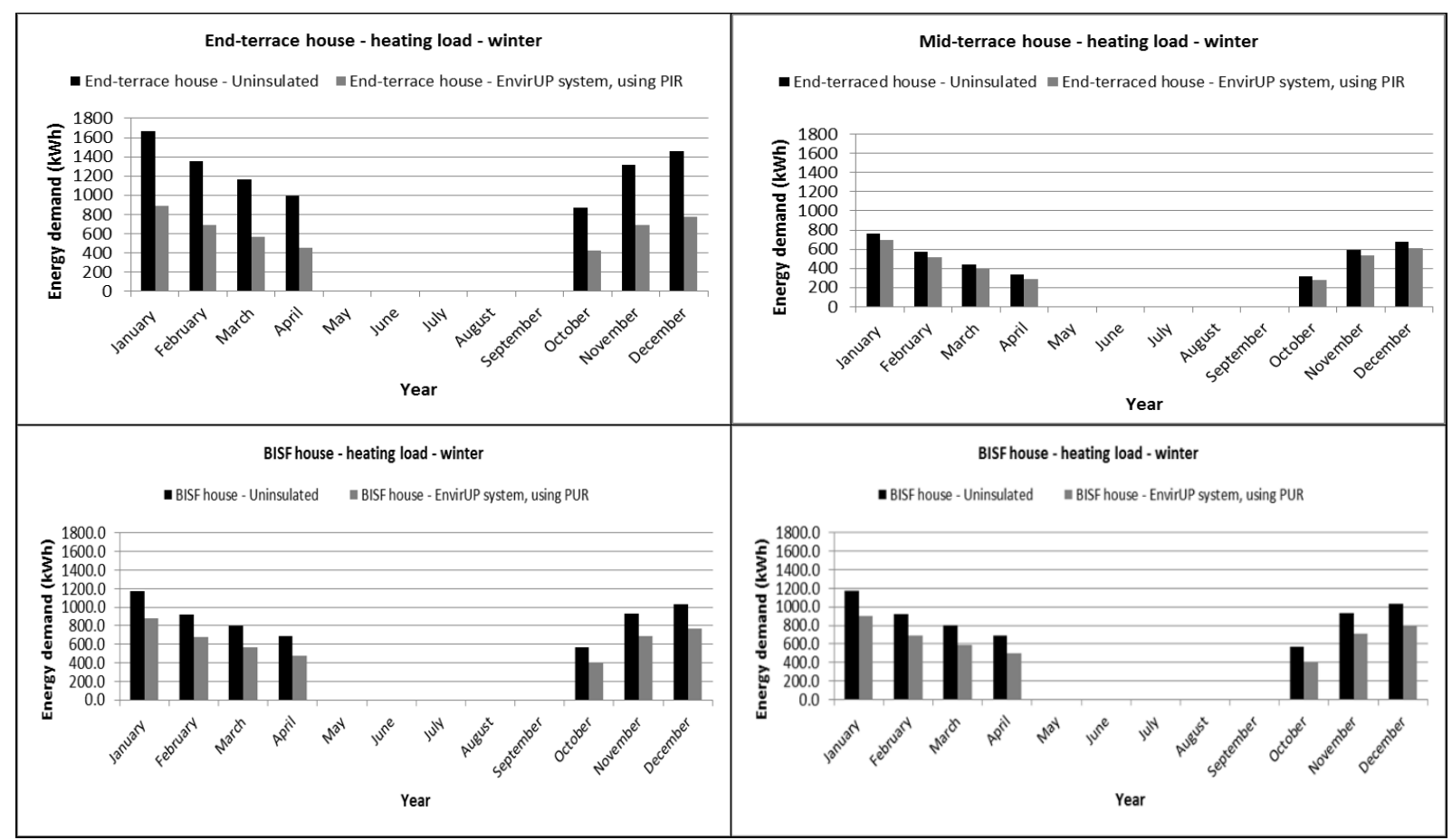

Figure 8: Monthly heating energy requirements for the End terrace solid brick wall property (left, top), the Mid-terrace cross-wall property (right, top), and the Semi-detached British Iron and Steel Federation (BISF) wall property with its original glass wool insulation and 50mm air gap (left, bottom) and without (right, bottom)

Table 4: Monthly and annual heating energy requirements for each simulated house in $\mathrm{kWh} / \mathrm{m}^{2}$

\begin{tabular}{|l|c|c|c|c|c|c|c|}
\hline \multirow{2}{*}{$\begin{array}{l}\text { Energy } \\
\text { demand } \\
\left(\mathrm{kWh} / \mathrm{m}^{2}\right)\end{array}$} & \multicolumn{2}{|c|}{$\begin{array}{c}\text { End terrace solid brick } \\
\text { wall property }\end{array}$} & \multicolumn{2}{c|}{$\begin{array}{c}\text { Mid-terrace cross-wall } \\
\text { property }\end{array}$} & \multicolumn{2}{c|}{$\begin{array}{c}\text { Semi-detached British Iron and Steel } \\
\text { Federation (BISF) wall property }\end{array}$} \\
\cline { 2 - 9 } & Uninsulated & $\begin{array}{c}\text { EnvirUP } \\
\text { system }\end{array}$ & Uninsulated & $\begin{array}{c}\text { EnvirUP } \\
\text { system } \\
\text { system } \\
\text { (with glass } \\
\text { wool) }\end{array}$ & $\begin{array}{c}\text { EnvirUP } \\
\text { system } \\
\text { (without } \\
\text { glass wool) }\end{array}$ \\
\hline January & 16.1 & 8.6 & 10.0 & 9.1 & 13.7 & 10.3 & 10.6 \\
\hline February & 13.0 & 6.7 & 7.6 & 6.8 & 10.8 & 7.9 & 8.1 \\
\hline March & 11.3 & 5.5 & 5.8 & 5.1 & 9.4 & 6.7 & 6.9 \\
\hline April & 9.6 & 4.4 & 4.3 & 3.8 & 8.0 & 5.6 & 5.8 \\
\hline October & 8.4 & 4.1 & 4.2 & 3.7 & 6.7 & 4.6 & 4.8 \\
\hline November & 12.7 & 6.6 & 7.7 & 7.0 & 10.9 & 8.0 & 8.2 \\
\hline December & 14.1 & 7.5 & 8.9 & 8.0 & 12.0 & 9.0 & 9.2 \\
\hline \hline Total & 85.2 & 43.3 & 48.5 & 43.5 & 71.3 & 52.0 & 53.5 \\
\hline
\end{tabular}

The resulting heating energy consumption required to maintain the fixed temperature of $21^{\circ} \mathrm{C}$ for the wall with no insulation was compared against the respective energy consumption of the EnvirUP EWI system. Figure 8 shows comparatively the energy demand performance, in kWh, of the two systems. Table 9 illustrates the annual and monthly heating energy requirements, in $\mathrm{kWh} / \mathrm{m}^{2}$, for each house type and wall configuration. This allows comparing the energy requirement per square metre of each of the houses.

It can be seen that the addition of the EnvirUP EWI system, reduced in $49 \%$ the heating energy demand of the end-terrace solid brick property. However, the use of this system on the timber wall construction of the mid-terrace house was less effective and the reduction of the heating energy demand corresponded to only $10.3 \%$. With regard to the BISF house, the reduction in energy demand amounted to $27.1 \%$ and $24.9 \%$ after the addition of the EnvirUP system with and without the additional glass wool layer respectively. 
The frequency of temperatures are shown in Figure 9. The results have been broken down for all the rooms of houses and the temperatures were correlated with the comfort criteria recommended by CIBSE (2006). In the end-terrace house, built out of masonry, the use of the EnvirUP system was able to reduce the temperature below $20^{\circ} \mathrm{C}$ from $67 \%$ to $56 \%$ of the year in the living areas and from about $61 \%$ to $46 \%$ in the master bedroom, when compared to the uninsulated walls. In terms of overheating, which occurs when the temperatures are above $28^{\circ} \mathrm{C}$, this was negligible in the occupied areas when using an uninsulated wall construction and this increased at maximum to $2 \%$ of the year in the occupied areas when adopting the insulation system.

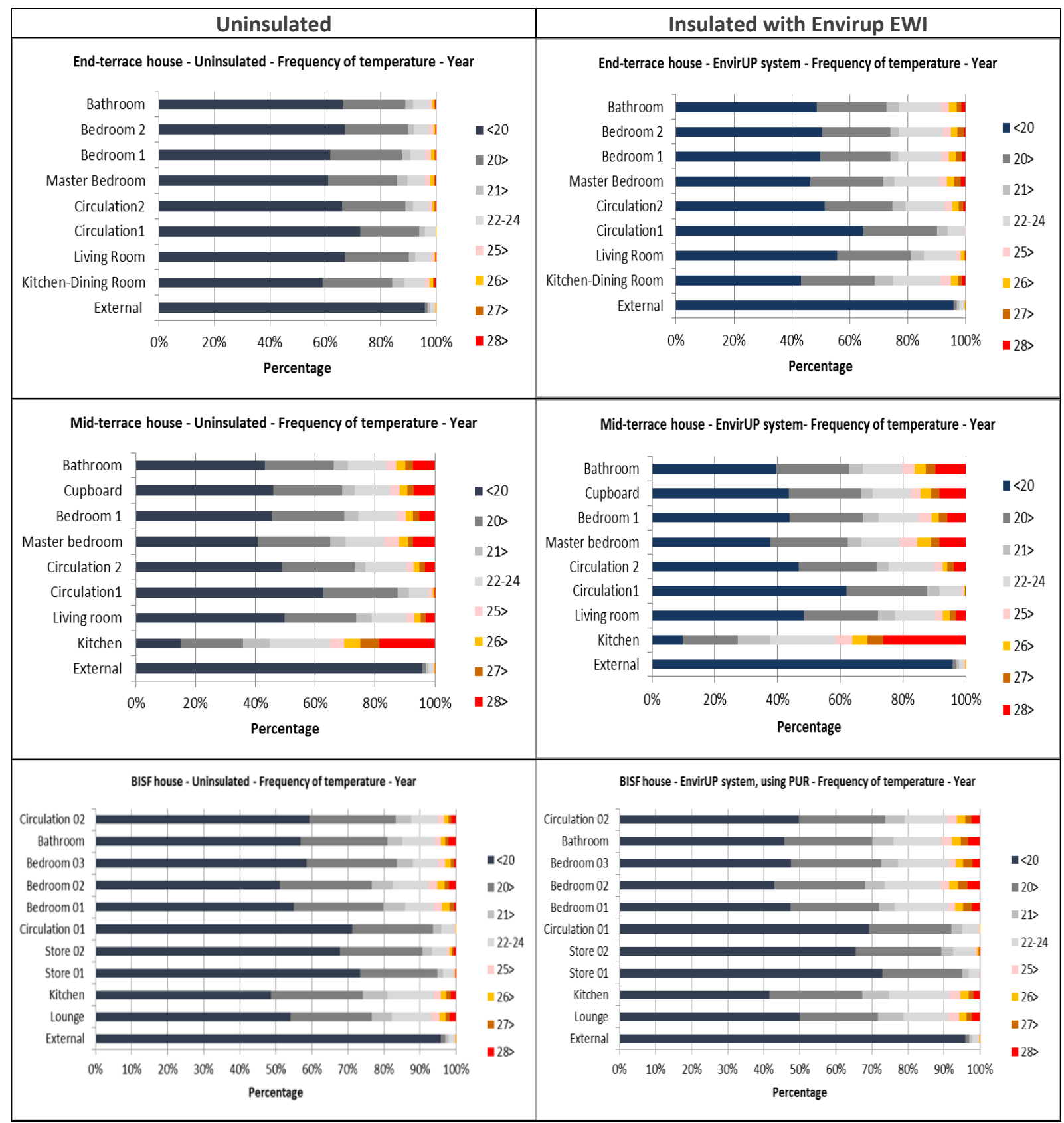

Figure 9: Yearly frequency of temperatures for the End terrace solid brick wall property (top line), the Mid-terrace cross-wall property (line 2), and the Semi-detached British Iron and Steel Federation (BISF) wall property (line 3)

In the timber framed mid-terrace house, the percentage of temperature below $20^{\circ} \mathrm{C}$ were already less significant when compared to the previous house and this corresponded to $50 \%$ and $41 \%$ of the year in the living areas and master bedroom, respectively. As expected, the addition of the EnvirUP system reduced slightly the percentage of temperatures below the lower comfort limit and this corresponded to $48 \%$ and $38 \%$ of the year in the living areas and master bedroom, respectively. Overheating increased about $1 \%$ in the 
occupied areas (in the master bedroom this changed from $7 \%$ to $8 \%$ of the year), when comparing uninsulated house against and the house with the use of EnvirUP system. However, it is noted that natural ventilation was not considered. The kitchen was found to have a significant overheating issue, which perhaps is due to its small area and orientation, combined with high internal gains due to the appliances and also the fact that the windows that were assumed to be permanently closed.

Within the BISF house, the percentage of temperatures below $20^{\circ} \mathrm{C}$ were somewhere in between the solid brick and cross-wall construction types. It corresponded to $54 \%$ and $55 \%$ of the year in the living areas and master bedroom, respectively. As expected, the addition of the EnvirUP system without additional glasswool insulation reduced the percentage of temperatures below the lower comfort limit and this corresponded to $50 \%$ and $48 \%$ of the year in the living areas and master bedroom, respectively. Surprisingly, when the glasswool insulation was included in the model alongside the EnvirUP product, it made very little difference to the output, with the percentage of temperatures below $20 \mathrm{C}$ remaining at $50 \%$ for the living area and reducing slightly to $47 \%$ for the master bedroom. Overheating prior to the installation of the EnvirUP system was present for approximately $2 \%$ of the year, increasingly marginally to $3 \%$ when the external wall insulation was applied.

Based on the assumptions used, the results suggest that the Envirup EWI system positively impacted on reducing the heating energy consumption and the number of hours below the comfort criteria of $20^{\circ} \mathrm{C}$ of the solid brick house. The heating energy demand would be reduced from 85.2 to $43.3 \mathrm{kWh} / \mathrm{m}^{2} /$ year (49\%). However, more limited benefits were observed by adding the EnvirUP system on the typical timber walls of the crosswall house: a reduction on heating demand of $5 \%$ (from 48.5 to $43.5 \mathrm{kWh} / \mathrm{m}^{2} / \mathrm{year}$ ). This is because these houses already have a lower u-value. In terms of the BISF construction, a reduction in the region of approximately $25-27 \%$ was observed, from 71.3 to 52.0 or $53.5 \mathrm{kWh} / \mathrm{m}^{2 /} /$ year depending on whether or not additional glass wool insulation was included in the wall build-up.

This compares to the steady state analysis, which estimated reductions in annual space heating demands of $42 \%, 11 \%$ and $36 \%$ for the solid brick, crosswall and BISF constructions respectively. These are all slightly more optimistic than those calculated through the dynamic modelling, as they are assessed based on static conditions, meaning that there is less scope for consideration of full occupancy and climate conditions.

\section{Conclusions}

In this article, the author presented the theoretical and experimental thermal performance assessment of an innovative external wall insulation system designed by Envirup to fit 'hard to treat' properties. A funded project allowed the team to develop the product from its initial ideas to its full maturity, leading to its first installation. The work undertaken by the project team informed the decision making process in terms of product composition and overall characteristics, and compared it to existing products in the market. This was followed by the work presented here, where representative properties that could receive the system were used to investigate its effectiveness.

The theoretical modelling, that used the Standard Assessment Procedure (SAP) protocols, suggested that the integration of the system resulted in thermal performance improvements for all construction types. Of particular significance, were the improvements for the solid wall and the BISF properties, with carbon emissions reduced by $34 \%$ and $28 \%$ and space heating demand reduced by $42 \%$ and $36 \%$ respectively. The improvement in performance for the cross-wall house was less pronounce, suggesting a reduction in carbon emissions of $8 \%$ and in space heating requirements in the region of $11 \%$.

The experimental work used a calibrated hot-box approach and the procedures suggest by the British Standards Institution (1999) for steady state and dynamic u-value testing. A prototype of each of the wall types present in the theoretical model were built and assessed. The measured steady state u-values were $0.59,0.53$ and $0.18 \mathrm{~W} / \mathrm{m}^{2} \mathrm{~K}$ for the BISF wall, the brick wall and the concrete wall respectively. The difference between the theoretical u-value measurement and the experimental steady state measurement was found 
to be in the order of $10-15 \%$ depending on the wall type. The measured dynamic u-values ranged from 0 to $1.10 \mathrm{~W} / \mathrm{m}^{2} \mathrm{~K}$, with a mean of $0.29 \mathrm{~W} / \mathrm{m}^{2} \mathrm{~K}$. The results from this experimental testing showed a difference between the predicted and measured $u$-values of the product in the case of all wall constructions, both in an insulated and uninsulated states. Whilst the u-values calculated as a result of the experimental work were less favourable than the theoretical results, the EnvirUP system has been found to be thermally effective. This test has also shown that the system is easy to install and requires minimum building skills.

Empirical data collected from a cross section of social housing properties in Nottinghamshire, UK was analysed to evaluate the effect of different occupant profiles on the energy usage of the dwellings. This included the information gathered from monitoring systems, alongside qualitative details of the households. From the sample assessed no obvious correlation was found between occupancy profile and energy use. However, when similar house types were compared, the influence of the occupancy was clear. The impact of the different building envelops was also notable.

A model of each of the typical properties was built in EDSL TAS 9.2.1.6 with assumptions informed by the empirical data analysis. The whole building analysis was performed in two parts: simulation of the houses in their current state and simulation of the houses with walls insulated with the EnvirUP prototype system. The addition of the EnvirUP EWI system, reduced in 49\% the heating energy demand of the end-terrace solid brick property. However, the use of the system in the cross-wall mid-terrace house was less effective and the reduction of the heating energy demand corresponded to only $10.3 \%$. In the BISF house, the reduction in energy demand amounted to $24.9 \%$ after the addition of the EnvirUP EWI system.

The information presented here confirms that the EnvirUP EWI system has the potential to considerably improve the thermal performance of 'hard to treat' properties, particularly solid brick wall and BISF house types. The savings demonstrated by the work undertaken are comparable to existing more established conventional EWI solutions. Therefore, the new system needs to offer additional benefits other than simple energy reductions in order to be accepted and used in place of 'known' products. The main unique selling point of the prototype system is that is does not require a wet render finish. This means that the installation of the product is not weather dependent, which is the case for many conventional systems. It is also prefrabricated off-site, which simplifies the installation process further and enables it to be completed in less time. These advantages, alongside equivalent thermal performance and potential lower cost, could be sufficient to allow the new system to penetrate the established EWI market.

\section{Acknowledgements}

The project team would like to thank the Technology Strategy Board for funding the project under the call 'Scaling up Retro Fit of the Nation's Homes'.

\section{References}

Baker P. (2011). U-Values and Traditional Buildings - In Situ Measurements and their Comparison to Calculated Values. Technical Paper 10. Historic Scotland Conservation Group. Edinburgh.

Beckett, D., 2014. Office for National Statistics Report -Trends in the United Kingdom Housing Market, 22nd September 2014. Retrieved 18th January 2015 from: www.ons.gov.uk/ons/dcp171766 373513.pdf [Last assessed 28.04.2017].

Bjarløv, S. P., Finken, G. R., Odgaard, T., 2015. “Retrofit with Interior Insulation on Solid Masonry Walls in Cool Temperate Climates An Evaluation of the influence of Interior Insulation Materials on Moisture Condition in the Building Envelope". Energy Procedia, Volume 78, 2015, Pages 1461-1466, ISSN 1876-6102. Available at http://www.sciencedirect.com/science/article/pii/S1876610215019037 [Last accessed 29.09.2017].

British Standards Institution (BSI), 1999. BS 874-3.2:1990: Determining Thermal Insulating Properties, Part 3: Tests for Thermal Transmittance and Conductance, Section 3.2 Calibrated Hot Box Method, London, British Standards Institution.

Building Standards Institute (BSI). (2008a). BS EN ISO 6946:2007 Building Components and Building Elements. Thermal Resistance and Thermal Transmittance. Calculation Method. BSI. London. 
Building Research Establishment (BRE), 2002. 'Non-traditional housing in the UK - A brief review'. Commissioned by the Council of Mortgage Lenders, written by Keith Ross of the BRE. Garston, Watford.

Building Research Establishment (BRE), 2012. 'Non-traditional houses - Identifying non-traditional houses in the UK 1918-75'. Edited by Harrison, H., Mullin, S., Reeves, B., Stevens, A. IHS BRE Press, Garston, Watford, UK. Available at https://www.brebookshop.com/samples/326979.pdf [Last accessed 29.09.2017].

Byrne, A., Byrne, G., O'Donnell, G., Robinson, A., 2016. 'Case studies of cavity and external wall insulation retrofitted under the Irish Home Energy Saving Scheme: Technical analysis and occupant perspectives'. Energy and Buildings, Volume 130, 15 October 2016, Pages 420-433, ISSN 0378-7788, https://doi.org/10.1016/j.enbuild.2016.08.027. Available at www.sciencedirect.com/science/article/pii/S0378778816307125 [Last assessed 28.04.2017].

CIBSE, 2006. 'Environmental Design: Guide A'. London, United Kingdom: The Chartered Institution of Building Services Engineers. Available at http://www.cibse.org/knowledge/knowledge-items/detail?id=a0q20000008179JAAS [Last accessed on 03.10.2017].

CIBSE, 2016. 'CIBSE Weather Data Sets - New Sets Released [2016]'. London, United Kingdom: The Chartered Institution of Building Services Engineers. Available at http://www.cibse.org/weatherdata [Last accessed on 03.10.2017].

Department for Business, Energy \& Industrial Strategy, 2014. 'Energy efficiency: Guidance for Standard Assessment Procedure'. First published 22 January 2013, Last updated 12 February 2014. Available at www.gov.uk/guidance/standard-assessment-procedure [Last assessed 28.04.2017].

Department for Business, Energy \& Industrial Strategy, 2017. '2015 UK Greenhouse Gas Emissions, Final Figures -Statistical Release: National Statistics'. National Statistics, London, UK. Available at www.gov.uk/government/collections/finaluk-greenhouse-gasemissions-national-statistics [last assessed 28.04.2017].

Department for Business, Energy \& Industrial Strategy, 2017. 'Annual Fuel Poverty Statistics Report, 2017 (2015 data)'. Statistical Release: National Statistics England, London, UK. Available https://www.gov.uk/government/uploads/system/uploads/attachment_data/file/639118/Fuel_Poverty_Statistics_Report_2017_re vised_August.pdf [Last accessed 28.09.2017].

Department for Communities and Local Government, 2017. 'English Housing Survey Headline Report, 2015-16' complied by the National Statistics, London, UK. ISBN: 978-1-4098-5014-4. Available at https://www.gov.uk/government/uploads/system/uploads/attachment data/file/595785/2015-16 EHS Headline Report.pdf [Last accessed 28.09.2017].

Di Giuseppe, E., lannaccone, M., Telloni, M., D’Orazio, M., Di Perna, C., 2017. 'Probabilistic life cycle costing of existing buildings retrofit interventions towards nZE target: Methodology and application example'. Energy and Buildings, Volume 144, 1 June 2017, Pages 416-432, ISSN 0378-7788, https://doi.org/10.1016/j.enbuild.2017.03.055. Available at www.sciencedirect.com/science/article/pii/S0378778817310319 [Last assessed 28.04.2017].

Doran S. (2000). DETR Framework Project Report : Field Investigations of the Thermal Performance of Construction Elements as Built. BRE. Glasgow.

Dowson, M., Poole, A., Harrison, D., and Susman, G., 2012. Domestic UK Retrofit Challenge: Barriers, Incentives and Current Performance Leading into the Green Deal. Energy Policy, 50(0), 294-305. doi: http://dx.doi.org/10.1016/j.enpol.2012.07.019.

Eames, M., et al. (2016). "An update of the UK's test reference year: The implications of a revised climate on building design." Building Services Engineering Research and Technology 37(3): 316-333.

EDSL (2009). Tas Theory Manual, EDSL documentation

EDSL, 2010. Tas 9.2.1 Dynamic Thermal Analysis Software. Milton Keynes, UK: Environmental Design Solutions Ltd.

Energy Saving Trust (EST), 2008. Energy Analysis Focus Report. A Study of Hard to Treat Homes Using the English House Condition Survey - Part 1: Dwelling and Household Characteristics of Hard to Treat Homes. DEFRA. London.

Energy Saving Trust (EST), 2010. Sustainable Refurbishment - Towards an 80\% Reduction in CO2 Emissions, Water Efficiency, Waste Reduction, and Climate Change Adaptation, CE309, Energy Saving Trust, London.

Feist, W., Pfluger, R., Kaufmann, B., Schnieders, J., and Kah, O., 2007. Passive House Planning Package 2007 - Requirements for Quality Approved Passive Houses. The Passivhaus Institut, Darmstadt.

Gaspar, P. L., Santos, A. L., 2015. "Embodied energy on refurbishment vs. demolition: A southern Europe case study". Energy and Buildings, Volume 87, 2015, Pages 386-394, ISSN 0378-7788, https://doi.org/10.1016/j.enbuild.2014.11.040. Available at http://www.sciencedirect.com/science/article/pii/S0378778814009712 [Last accessed 29.09.2017].

Gillott, M., Rodrigues, L., Spataru, C., 2010. "Low-carbon housing design informed by research". Proceedings of the Institute of Civil Engineering - Engineering Sustainability 163 (2): $77 \quad-87 . \quad$ ICE Publishing, London. Available at http://www.icevirtuallibrary.com/content/article/10.1680/ensu.2010.163.2.77 [Last accessed 24.04.2017].

Gill Z., Tierney, M. , Pegg. I, Allan, N., 2010. Low-Energy Dwellings: The Contribution Of Behaviours To Actual Performance, Building Research and Information, 38:5, 491-508 
Gooding, L., Gul, Mehreen S., 2017. 'Achieving growth within the UK's Domestic Energy Efficiency Retrofitting Services sector, practitioner experiences and strategies moving forward'. Journal of Energy Policy, Volume 105, June 2017, Pages 173-182, ISSN 03014215, https://doi.org/10.1016/j.enpol.2017.02.042. Available at www.sciencedirect.com/science/article/pii/S030142151730126X [Last Accessed 24.04.2017].

Harter, H., Weiler, V., Eicker, U., 2017. "Developing a roadmap for the modernisation of city quarters - Comparing the primary energy demand and greenhouse gas emissions". Building and Environment, Volume 112, 2017, Pages 166-176, ISSN 0360-1323. Available at http://www.sciencedirect.com/science/article/pii/S0360132316304553 [Last accessed 22.07.2017].

Harter, H., Weiler, V., Eicker, U., 2017b. “Life cycle assessment of buildings and city quarters comparing demolition and reconstruction with refurbishment". Energy and Buildings, Volume 134, 2017, Pages 319-328, ISSN 0378-7788. Available at http://www.sciencedirect.com/science/article/pii/S0378778816314141 [Last accessed 22.07.2017].

Jones, R. V., Fuertes, A., Boomsma, C., Pahl, S., 2016. 'Space heating preferences in UK social housing: A socio-technical household survey combined with building audits'. Energy and Buildings, Volume 127, 2016, Pages 382-398, ISSN 0378-7788, https://doi.org/10.1016/j.enbuild.2016.06.006. Available at www.sciencedirect.com/science/article/pii/S0378778816304960 [Last accessed on 03.10.2017].

Kolokotsa, D., Santamouris, M., 2015. "Review of the indoor environmental quality and energy consumption studies for low income households in Europe". Science of The Total Environment, Volume 536, 2015, Pages 316-330, ISSN 0048-9697. Available at http://www.sciencedirect.com/science/article/pii/S0048969715304162 [Last accessed 22.07.2017].

Langevin, J., Gurian, P.L., Wen, J., 2013, Reducing energy consumption in low income public housing: Interviewing residents about energy behaviours, Applied Energy, Volume 102, February 2013, Pages 1358-1370, ISSN 0306-2619, http://dx.doi.org/10.1016/j.apenergy.2012.07.003.

Leth-Petersen, S., Togeby, M., 2001. Demand For Space Heating In Apartment Blocks: Measuring Effect Of Policy Measures Aiming At Reducing Energy Consumption, Energy Economics, 23 (2001), pp. 387-403

National Physical Laboratory (NPL), 2017). 'Thermal Performance - characterising thermophysical properties of materials'. Available at http://www.npl.co.uk/science-technology/thermal-performance/ [Last accessed 03.10.2017].

Power, A., 2008. Does Demolition or Refurbishment of Old And Inefficient Homes Help To Increase Our Environmental, Social and Economic Viability? Energy Policy, 36(12), 4487-4501. doi: http://dx.doi.org/10.1016/j.enpol.2008.09.022 [Last Accessed 24.04.2017].

Roaf, S., Baker, K., and Peacock, A., 2008. 'Evidence on Tackling Hard to Treat Properties'. The Scottish Government Housing and Regeneration Department. Edinburgh.

RUSFA, 2017. 'Sapper software'. Charlbury, Oxon, UK. Available at http://www.rusfa.com/ [Last accessed on 03.10.2017].

Santamouris, M., 2016. "Innovating to zero the building sector in Europe: Minimising the energy consumption, eradication of the energy poverty and mitigating the local climate change". Solar Energy, Volume 128, 2016, Pages 61-94, ISSN 0038-092X, https://doi.org/10.1016/i.solener.2016.01.021. Available at http://www.sciencedirect.com/science/article/pii/\$0038092X16000359 [Last accessed 29.07.2017].

Santin, O., Itard, L., and Visscher, H., 2009. The Effect Of Occupancy And Building Characteristics On Energy Use For Space And Water Heating In Dutch Residential Stock, Energy and Buildings, Volume 41, Issue 11, November 2009, Pages 1223-1232

Siviour J. (1981). BIBINF Proceedings International Colloquium "Comparative Experimentation of Low Energy Houses" Liege, 6-8 May 1981.

Stafford, A., Gorse, C. and Shao, L., 2011. The Retrofit Challenge: Delivering Low Carbon Homes. Leeds Sustainability Institute, Leeds Metropolitan University, Centre for Low Carbon Futures and Energy Saving Trust. Available at http://www.superhomes.org.uk/wpcontent/uploads/2012/01/Retrofit Challenge 2011.pdf [Last Accessed 03.02.2017].

Tetlow, D., Shatat, M., Riffat, S., 2015. 'The retrofitting of an old style semi-detached house for energy reduction and carbon savings under the UK climate'. International Journal of Low-Carbon Technologies 2015. 10, 119-130.

White, J., Rodrigues, L., Gillott, M., 2015 (a). “The influence of occupancy on energy profiles in social housing”. In: 31 $1^{\text {st }}$ International Conference on Passive and Low-Energy Architecture PLEA 2015: Architecture in (R)Evolution. Bologna, Italy, 9-11 September 2015.

White, J., Rodrigues, L., Gillott, M., Tubelo, R., 2015 (b). “An Innovative External Wall Insulation System for Energy Efficient Refurbishment of Houses". In: RODRIGUES, L. ed., 2015. 'Sustainable energy for a resilient future: Proceedings of the $14^{\text {th }}$ International Conference on Sustainable Energy Technologies- SET 2015', 25th to 27th of August 2015, Nottingham UK. The University of Nottingham Eprints. Volume I, pages 351-360. Available from http://eprints.nottingham.ac.uk/id/eprint/34706 [Last Accessed 03.02.2017].

Wingfield J., Bell, M., Miles-Shenton, D., and Seavers, J. (2011a). Elm Tree Mews Field Trial - Evaluation and Monitoring of Dwellings Performance - Final Technical Report. In Centre for Built Environment (Ed.), Leeds Metropolitan University. Leeds.

Wingfield J., Bell, M., Miles Shenton, D., South, T., and Lowe, B. (2008). Evaluating the Impact of an Enhanced Energy Performance Standard on Load-Bearing Masonry Domestic Construction - Report Number 8: Final Report Lessons from Stamford Brook - 
Understanding the Gap between Designed and Real Performance. In C. f. t. B. Environment (Ed.), Leeds Metropolitan University. Leeds.

Woodford, C., 2014. Heat Insulation. Retrieved 19th May 2014, from http://www.explainthatstuff.com/heatinsulation.html [Last assessed 28.04.2017].

Zero Carbon Hub. (2013a). Closing the Gap Between Design and As-Built Performance - New Homes - Interim Progress Report July 2013. Zero Carbon Hub. London. 